\title{
EXPERIENCES OF SOCIAL PARTICIPATION IN RECOVERY TO RECONNECT A COMMUNITY TO ITS HERITAGE
}

\author{
P. de Dato ${ }^{1, *}$, Y. Hernández Navarro ${ }^{1}$ \\ ${ }^{1}$ Universitat Politècnica de València - (pasdeda, yoherna)@upv.es;
}

Commission II - WG II/8

KEY WORDS: Lost heritage, Social participation, Vernacular heritage, Tuejar, Villargordo del Cabriel, Recovery experiences

\begin{abstract}
:
Intervention in private vernacular heritages often causes of the loss of its cultural values in the same way as its abandonment brings it to a condition of irreversible ruin. This reflection is valid for public heritage, but in this sphere the detachment caused by ignorance, forgetfulness and contempt, contrasting with the very idea of heritage, seems to be more serious. This work starts from the reflection on the degradation of certain historical-cultural resources due fundamentally to the lack of maintenance and abandonment, leading to a strategy based on social participation as a key to success in the recovery of heritage in general. The proposal is born from the analysis of the successful intervention experiences of different assets which from the beginning have incorporated the direct and active participation of the respective communities, not only in the enhancement of the assets once they have been intervened, but also in the physical process of the intervention through craftsmanship based on the traditional trades of construction. In both cases presented in this study direct participation has allowed the traditional construction techniques and their associated cultural values to become known, to train the population in techniques to guarantee the maintenance of heritage resources in the future, to recover traditions, ethnographic culture and local history, and finally to rebuild the broken links of attachment to the cultural heritage.
\end{abstract}

\section{INTRODUCTION}

\subsection{About detachment from heritage}

In the definition of heritage, modern philology follows two apparently different etymological lines whose differences lie in a nuance within the same meaning of inheritance.

The most direct etymological definition is that heritage, from the Latin patrimonium, is the set of goods which children inherit from their parents. The other meaning, however, delves deeper into the original composition of theword, separating the patris (of the father) from the monium (from the Latin verb monere), referring to remembrance, reminding, so that patrimonium can mean a set of inherited goods which are a reminder of the father who passed his legacy on.

In Ancient Roman culture heritage was a serious matter, a body of wealth handed down from generation to generation in order to preserve it. However, more importantly it was the memory of the ancestors, who were even deified as Lares, protectors of the family, and who were the center of daily and family rituals.

As these Lares have been lost in the cultures which have now succeeded the Roman one, the meaning of heritage as memory has also been lost. As stated by Julián Esteban Chapapría, "both its biological and psychological aspects are only the results of dynamic systems of organization and exist only to the extent that the organization maintains or reconstitutes them". He also adds that losing collective memory can lead voluntarily or involuntarily to the creation of identity disorders in peoples and alterations in the history of their common past. (Esteban, 2016)

Each generation must accept ownership of the obligations entailed by heritage, keeping them up to date. This means that the community shares its past in a process of searching for roots (the past), to build something in common (present) (Alba, 2014).

The vernacular architectures that have remained until today, often fortuitously, and the places on which they are based, are bulwarks of resistance of collective memory. Their study and conservation, in line with the Franceschini commission for the Hague Declaration of 1954, which proposed to attach more value to the action of human production than to the material object itself, makes it possible to rescue the know-how, traditions, and history of our ancestors: our identity.

However, the systematic destruction of what is not admitted as a sign of self-identity for cultural, religious, ideological or stylistic values has frequently been and is being witnessed. (Alba, 2014)

In the words of De Rueda, "the worst enemy of cultural heritage is armed conflict, not only because of the damage caused by the bombings, but also because of the vandalism which frequently emerges among the troops or the people venting against artistic and other works of historical, literary, scientific interest ..., and human greed, which clings to various goods, transporting them, sometimes in unacceptable conditions, to different places based on protection, conservation or rescue criteria which most of the time mask very different reasons" (De Rueda, 1999a).

In contrast, an even worse enemy of heritage is the unexpected threat from within, such as the loss of roots, especially of the younger generations.

This is caused primarily by a lack both of knowledge of the heritage and of social awareness which prevent its recognition

\footnotetext{
* Corresponding author
} 
and protection, giving rise to the loss of related techniques and hindering its maintenance and conservation (Carmona, de Dato, 2019).

The Tuéjar wash houses and the Cuestas de Contreras trenches are clear examples of this situation, both located in Spain. The wash houses and trenches were found in a state of general degradation, caused by vandalism and the lack of maintenance by the local population, given their contempt and loss of roots. In the case of the trenches, most of the population was even unaware of their existence.

\section{EXPERIENCES OF SOCIAL PARTICIPATION IN THE RECOVERY}

\subsection{Conservation and management strategies of Tuéjar wash houses}

Given their operation and use the Tuéjar wash houses can be considered part of the vernacular architecture for work ${ }^{1}$, where the male-dominated world of farm work and its irrigation system is mixed with the women's world of domestic chores.

It is a sparse and functional architecture, with hardly any ornamentation or stylistic pretensions, but also charged with cultural and symbolic values which reflect the organization of individual communities and power struggles with neighboring communities.

Five wash houses known as "San Juan", "la Hondonera", "Chorrillo", "la Rocha" and "la Fuente la Rocha" remain, dating from the beginning of the 20th century. These are located in a peri-urban setting on the border between the town and the orchards and follow the local constructive tradition with masonry, wooden covering, reed and tile and whitewashed with slaked lime.

Throughout their history, most have undergone radical modifications transforming their vernacular character, which was closely linked to the landscape, while those which were abandoned retained their most authentic appearance despite being in a state of ruin.

A survey of a significant sample of inhabitants prior to the interventions showed that most of the local population over the age of fifty knew the wash houses and/or had used them once, although they did not recognize their cultural values or consider them to be heritage.

However, the data became less encouraging when surveying the population below that age. The younger generations only displayed knowledge of the most urban washrooms or those related to some local scandal and did not attach any value to them (Figures 1 and 2).

Between 2015 and 2016, the group of wash houses was intervened to rescue them from degradation, organizing a thematic route around water.

One of the key factors for their recovery has been the dissemination of historical research and the techniques used in the intervention.

\footnotetext{
1 Vernacular architecture for work is understood as all constructions that do not belong to the category of industrial or proto-industrial architecture and are intrinsically related to domestic, agricultural and artisan work.
}

Following conservation and restoration work on the wash houses, and coinciding with their inauguration, children's education and primary schools from the town took part in activities where students were able to have direct experience of the wash houses.

The workers involved in the intervention were also in charge of describing each of the wash houses on site, their relationship with the environment, and the techniques for using water, from the river to the ditches.

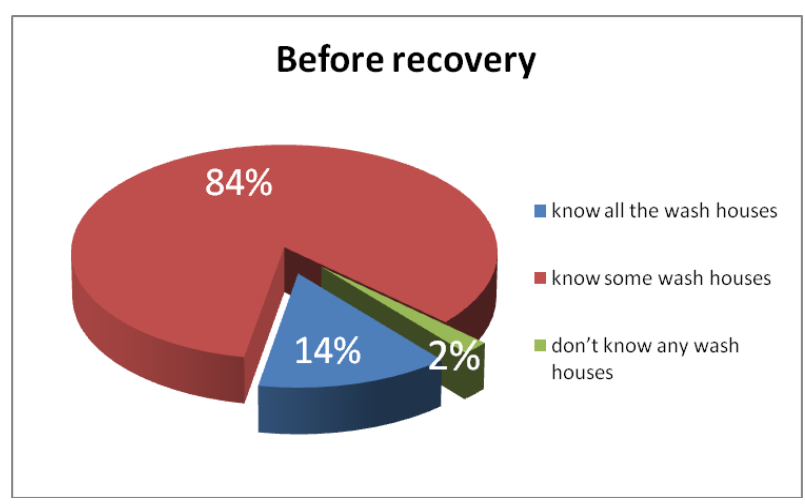

Figure 1. Survey on the knowledge of the wash houses before recovery among population under fifty.

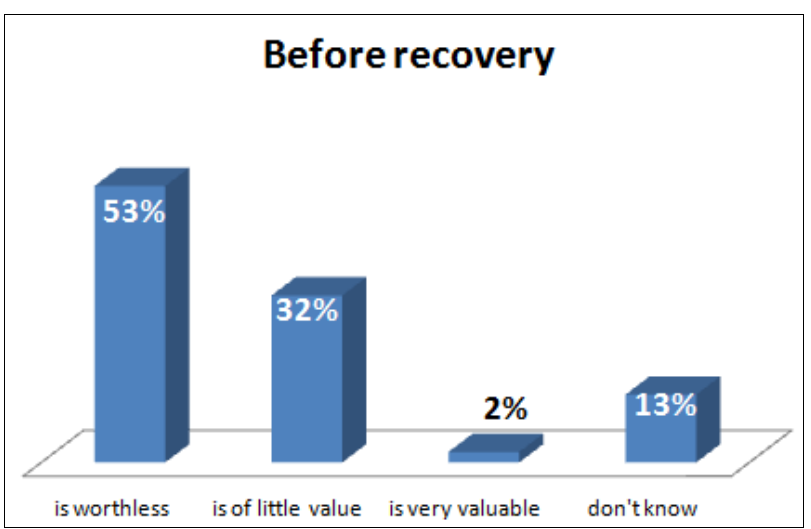

Figure 2. Survey on the attributed value to wash houses before recovery among population under fifty.

The washing of garments, as practiced by their forebears, was explained. Students were able to experience their dynamics, materials, and strategies, recovering the oral and practical transmission which was halted by the introduction of washing machines to the home (Figure 3 ).

The constructive characteristics of the wash rooms were also explained with practical demonstrations of the construction of a roof with a wooden structure, reed and tiles, liming of walls, etc., following the techniques traditionally used for construction, taking advantage of local materials. Students were able to test these same techniques in a hands-on workshop led by the workers.

In addition, popular songs were sung with the aim of recreating and transmitting the social relationships which had developed around wash houses. This new route designed between the urban and rural context helped to strengthen the old link between town and heritage. 
However, the recovery is an even greater achievement in itself, not so much for the work done but rather for how it was carried out.

The recovery of heritage is normally assigned to specialist or non-specialist companies, working for profit following technical projects and the guidance of professionals. They do not usually have any emotional relationship with the asset on which the intervention is carried out.

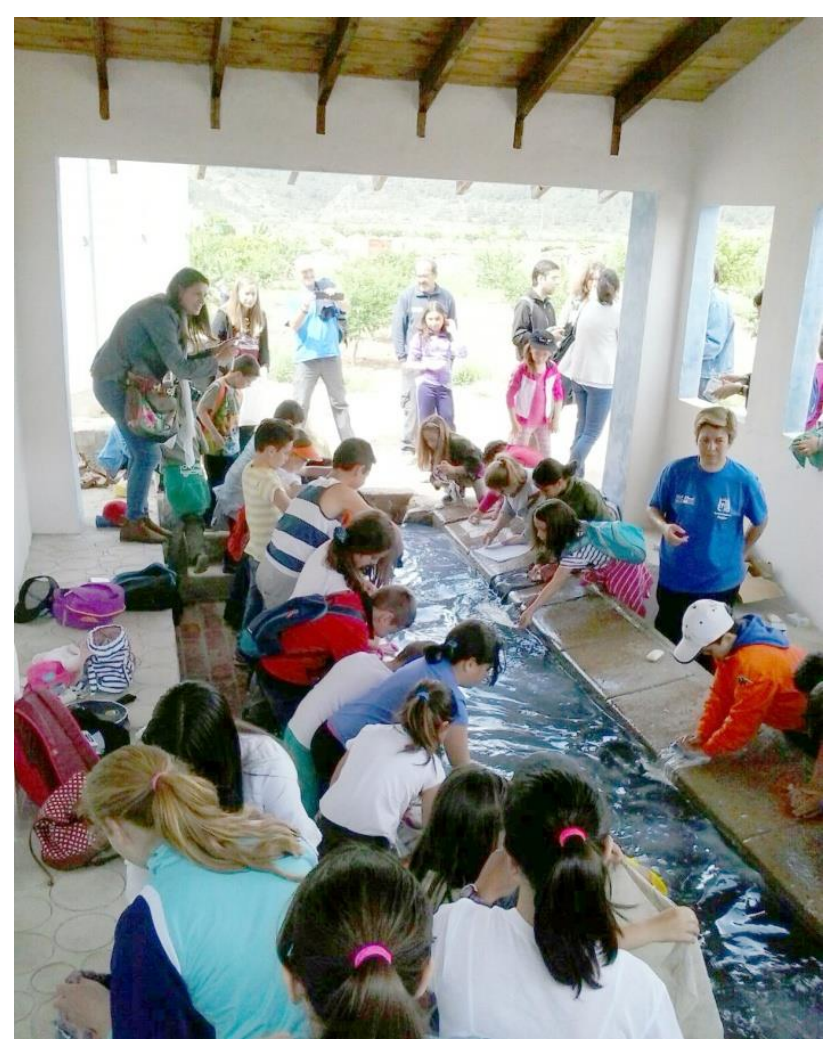

Figure 3. Social participation in the inauguration for the recovery of the wash houses of Tuéjar.

In the case of the Tuéjar wash houses, however, the intervention was carried out by students from a vocational training program for work-linked employment.

This workshop is one of the dual training modalities which alternate training and work to obtain a certification of professional skills. Students are usually local and from poorer backgrounds or are unemployed and their theoretical training is combined with real practical work experience to improve their professional possibilities.

In the case of Tuejar, the objective of the workshop's practical action was the intervention to recover the wash houses. Over a six-month period, fifteen student-workers studied and put into practice vernacular construction techniques, traditional materials and their use, the history of the infrastructure of their town, as well as the reasoning and praxis of the recovery of heritage and, above all, its cultural values. The greatest success was the involvement of local residents in the study and restoration of heritage. These people rediscovered a heritage they barely knew, finding out how important these infrastructures were to their ancestors, while also dusting off memories and experiences that were part of their collective memory and reestablishing emotional ties not only with the wash houses but with their heritage in general.
However, a much more important effect was that of contagion, which meant that this interest and attachment spread, not only through direct dissemination to the students of the schools, as stated previously, but also to the rest of the population.

In parallel, an investigation was carried out on the customs and use of wash houses, interviewing women (aged between 77 and 92) who had used these wash houses regularly in their youth.

These interviews provided information not only on the history and operation of the wash houses, but also recovered the stories and experiences of these women, most of whom had used the wash houses, contributing to the recovery of collective memory.

\subsection{Results}

The population interviewed at the end of the interventions and organized events confirm that the data on knowledge and valuation of the wash houses have changed radically as shown in the graphs below (Figures 4 and 5). Proof of the recovery of these links lies is the fact that Tuéjar town council annually organizes a team of workers for the maintenance of the wash houses and other local heritage, including workshop students in order to increase their experience and awareness.

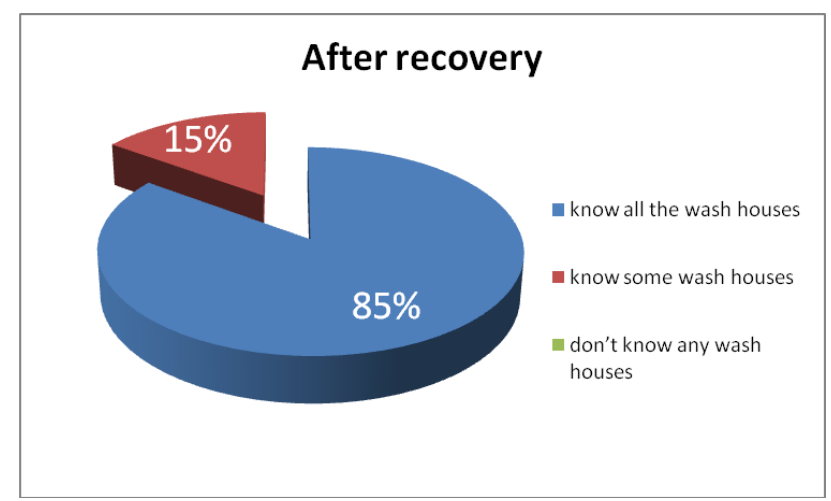

Figure 4. Survey of the knowledge of the wash houses in population under fifty years after recovery.

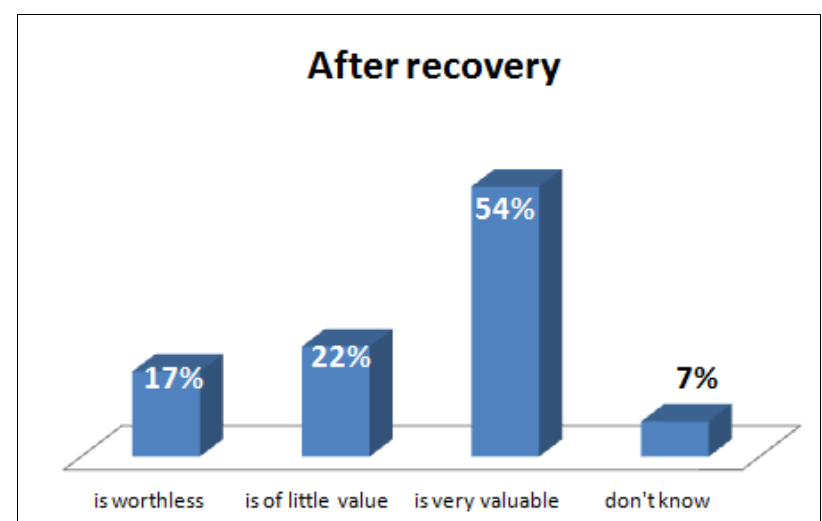

Figure 5. Survey on the attributed value to wash houses in population under fifty years after recovery.

An annual walk through the wash houses is planned, with students from local and nearby schools. Training, acquired knowledge and love for heritage have spread from the first group to the rest of the population who have come to recognize heritage as a source of employment and a way to reactivate the local economy by promoting tourism. 
In fact, a tourist route of the Tuéjar wash houses has been promoted, creating a flow of visits in the town that not only shares the experience and cultural heritage of water management in the interior regions, but also feeds back the perception of the value of heritage as an economic driving force. All this has laid the foundations for the promotion of awareness of local heritage in general.

\subsection{Conservation and management strategies for the trenches of Villargordo del Cabriel}

The set of defensive lines known as Trincheras de las Cuestas de Contreras is located in the upper part of the slopes on the route from the town of Villargordo del Cabriel to the village of Contreras within the Hoces del Cabriel Natural Park. It is made up of the Peñas Blancas Road Trench, the Huerta La Carpia Trench and the Minglanilla Road Trench and is easily accessible from the CV-4661 road.

The three trenches are inventoried in the Inventory of Ethnological Resources of the Valencian Community of the General Directorate of Heritage of the Ministry of Education, Culture and Sport (Inventario de Bienes Etnológicos de la Comunidad Valenciana de la Dirección General de Patrimonio de la Conselleria de Educación, Cultura y Deporte) dated to the period 1936-1939, and therefore coinciding with the Civil War. (de Dato, Hernández, 2020).

Despite this inventory and easy accessibility, very few inhabitants of the region actually knew of their existence, far less their location. Hence, ignorance and lack of political will have meant that no interest has been previously expressed in recovering them from oblivion and dilapidation.

In 2014, however, on the occasion of the completion of the Catalog of Protected Resources of the General Management Plan of Villargordo del Cabriel, the potential of the historical heritage assets scattered in the area was discovered.

The City Council promoted the recovery of all the trenches whose poor conservation was causing structural and specific collapse problems. In addition, these were buried under the sedimentation deriving from the erosion of the rear parapets and earth shifted during rainy periods, while the trenches had in fact been used as a dump for some time, further contributing to the public's lack of knowledge.

When the population was surveyed on this topic, the vast majority had not even visited these places, whereas the few interviewees who did know of the presence of trenches and military elements in the town, almost all confused the Civil War military constructions with a group of trenches which this investigation dates from the War of Independence (de Dato, Hernández, 2020). In fact, other trenches from the same period are known to exist but have not yet been located.

However, these heritage resources have great historical and documentary value for the military events which took place in these locations, both in terms of local and national history.

As in the previous case, intervening in these resources has generated different positive impacts due not only to the physical recovery of historic elements from decay and abandonment, but also at a social level. In fact the interest generated has led to the active participation of local residents in the organization of the historical recreations of the military actions that took place there.

To date, two dramatic recreations of military events have been organized with a large local participation, with performances from theatrical groups, as well as the organization of children's workshops, parades, and meals, which have also helped to attract and involve foreign visitors who have come specifically for the occasion.

The first of these events, on the occasion of the completion of the work, was a participatory cultural milestone which fostered local awareness of heritage assets, considered not as dead elements of the past but as active heritage for social, economic and cultural development

This is reflected in the fact that the experience was repeated years later, with even more visitors taking part. The tourist impact generated by the promotion of these events should also be noted, as well as the influence of the resources recovered and their inclusion in new scenic routes of the Hoces del Cabriel Natural Park.

However, in terms of the intervention carried out it is necessary to emphasize that the project guidelines aimed to respect the essential characteristics and values of the resources, their technical and constructive identity and to preserve their volumetric, spatial and morphological characteristics following criteria for sensible and reversible conservation actions.

The most relevant aspects of the intervention also relate to participatory management.

Firstly, taking into account the strict relationship between these properties and their surrounding landscape, the maintenance of the natural landscape stands out, as it has foreseen a large-scale intervention on the territory, in collaboration with the forest brigades of the Natural Park, through the programming and completion of felling of timber to restore and maintain the original observation points, and botanical advice on existing tree species and their characteristics.

Secondly, the management of the recovery tasks, directly carried out by the City Council, through its qualified technical personnel and including the hiring of local labor. Unlike the previous case, the unemployed workers were registered at a job center and had experience in the construction sector.

The supplies of machinery, tools and materials were also managed directly by the city council. This model of execution of work with constant technical supervision as in a workshop, has provided paid work to the groups most severely affected by the last economic crisis, in addition to ensuring its correct execution. It has also allowed the workers to broaden their technical and professional knowledge in terms of heritage recovery, in what can be a very rigid and flawed sector conceptually, and to improve their work horizons.

In addition, the cost of the intervention, $86 \%$ of which was subsidized, has been used mainly $(65 \%)$ in hiring local labor and $30 \%$ has been used to purchase material that is also locally sourced. In other words, the intervention in heritage has generated direct economic benefit for the local population. 


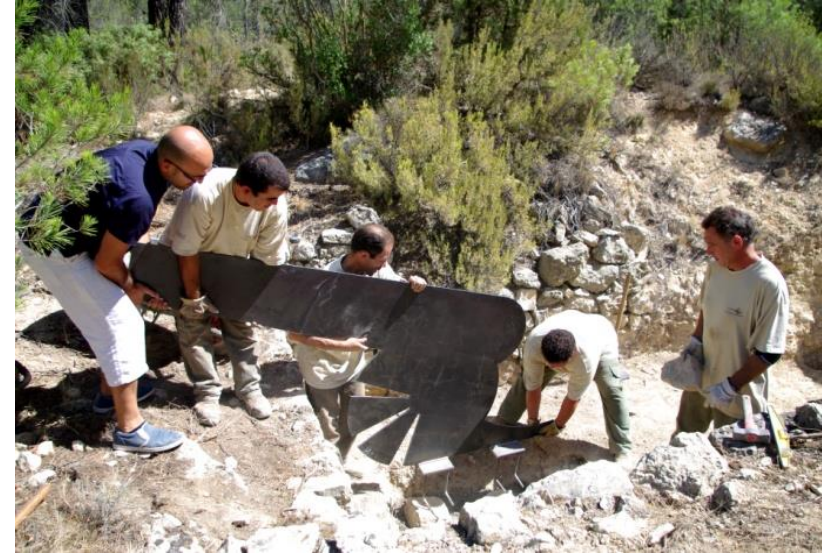

Figure 6. Unemployed people hired in the recovery of the trenches of Villargordo del Cabriel.

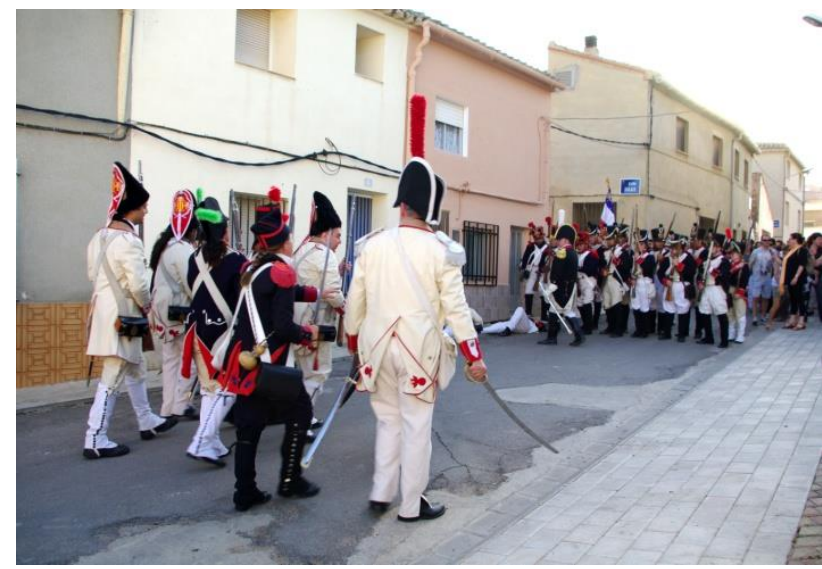

Figure 7. Social participation in commemorative events after the recovery of the trenches of Villargordo del Cabriel.

\subsection{Results}

The valorization of the complex has required exhaustive research establishing the historical knowledge of the events that occurred in the site of the heritage complex. The dissemination of this research through panels, explanatory tables and guided visits to the complex reveals the impact of the intervention in the educational and cultural field.

Another notable aspect is that of the inclusion in local school programs, putting its heritage into context when teaching history, as well as the voluntary organization of the different neighborhood associations taking part annually in commemorative events (Figure 7).

The rediscovery of its heritage has been so important for the local Villargordo del Cabriel community that not only does everyone know about the Trenches of Cuesta de Contreras and their location, but they have also found out about history and related war events. The links re-established with these resources as a result of the recovery experience have launched an action plan for the creation and management of a Cultural Park that brings together the heritage elements of the area, conserving and combining them.

The purpose of improving the management of cultural resources and their dissemination through tourist promotion of the municipality and its patrimonial and natural wealth translates into a set of actions aimed at cultural and economic revitalization feeding the sustainable development of a rural community.

In short, it was possible to make the local population perceive the existing architectural resource, not as something old and useless, but as a valuable asset capable of creating wealth.

\section{CONCLUSIONS}

Vernacular architecture is made up of the landscape in which it is found; its materiality is the result of the environment and the know-how of the techniques used locally by the populations.

Breaking the balance between environment, technique and materiality does not only have repercussions on the conservation of the building, but also has a negative impact on the cultural and landscape level (de Dato, Carmona, 2017), in other words, on memory.

Conveying the importance of traditional material and technique in vernacular architecture guarantees the survival of the identity of a community. For this, a sensible approach and an attitude of respect are of prime importance in recovery, and those intervening should seek modesty and integration rather than a position of predominance.

And for this, in the experiences explained above, the use of local labor, even unskilled, has been instrumental in reinforcing the handmade character of traditional architecture.

Secondly, overcoming the resistance of contemporary praxis in construction and recovering the constructive and linguistic memories of vernacular architecture requires considerable didactic and practical efforts. Social participation in recovery processes allows the relationship of affection between population and heritage to be restored.

But above all, it allows us to recover the places of memory where architecture captures the passing of our ancestors, embodied in the materials and designs of their constructions (Nora, 1992), to transform it into a greater value for collective learning.

\section{REFERENCES}

Alba Pagán, E., 2014: Fundamentos para la gestión del Patrimonio cultural. In AA.DD, El desarrollo territorial valenciano. Reflexiones en torno a sus claves. 169-188. Universitat de València.

Carmona, Mª.E., de Dato, P., 2019: Arquitectura rural de la Serranía: Los lavaderos de Tuéjar. Instituto de Estudios Comarcales Hoya de Buñol-Chiva, Valencia.

de Dato, P., Carmona, M ${ }^{a}$.E., 2015: Una experiencia de recuperación del patrimonio: la ruta de los lavaderos en Tuéjar. In Actas del II Congreso TRADIArq, 418-424. TC Cuadernos, Valencia.

de Dato, P., Hernández, Y., 2015: Las trincheras de las Cuestas de Contreras. Ejemplo de buenas prácticas en la intervención sobre el patrimonio. In Actas del I Congreso TRADIArq, 418424. TC Cuadernos, Valencia. 
The International Archives of the Photogrammetry, Remote Sensing and Spatial Information Sciences, Volume XLIV-M-1-2020, 2020 HERITAGE2020 (3DPast | RISK-Terra) International Conference, 9-12 September 2020, Valencia, Spain

de Dato, P., Hernández, Y., 2020: Synergy of different historical-architectural analyses for the dating of military remains: the trenches on the slopes of Contreras. Unpublished manuscript.

De Rueda Roigé, FJ, 1998-1999a. La protección internacional del patrimonio cultural en caso de conflicto armado. Locvs Amoenvs, 4, 249-266. doi.org/10.5565/rev/locus.97

Esteban Chapapría, J., 2015: Patrimonio, memoria y paisaje en la Serranía de Valencia, In Actas del I Congreso TRADIArq, 1423. TC Cuadernos, Valencia.

Nora, P., 2008: Pierre Nora en Les lieux de mémoire. Ediciones Trilce, Montevideo 